\title{
Chemical Composition, In Vitro Digestibility And Gas Production Characteristics Of Diets Containing Sweet Orange (Citrus Sinensis) Peel Meal
}

\author{
${ }^{1}$ J. Oloche., I.O.A. Oluremi and Ayoade, J.A \\ ${ }^{1}$ Department of Animal production, University of Agriculture, Makurdi \\ *Department of Animal Nutrition, University of Agriculture, Makurdi
}

\begin{abstract}
The nutritive value of four diets containing different levels of sweet orange peel meal (SOPM), $D_{I}(0 \% S O P M), D_{2}(12.5 \% S O P M), D_{3}(25 \% S O P M)$ and $D_{4}(50 \%$ SOPM $)$ were evaluated in terms of their chemical composition, in vitro gas production (IVGP), metabolizable energy (ME), organic matter digestibility $(O M D)$, short chain fatty acids (SCFA) and in vitro gas production characteristics. Results showed that the in vitro gas production characteristics did not show any significant difference $(p>0.05)$ among treatments. The values for potential gas production ' $b$ ' and the potentially degradable fractions ' $a+b$ ' for all the dietary treatments were similar ( $p>0.05$ ), but absolute values of $D_{4}(50 \%$ SOPM) for ' $b$ ' and ' $a+b$ ' (30.88 and 38.59) respectively, were higher than those of $D_{1}, D_{2}$ and $D_{3}$. The rate of fermention ' $c$ ' was also similar across the treatments. In vitro gas production volumes were significantly affected $(p<0.05)$ among the treatments. Metaboliazable energy for $D_{4}(6.56 \mathrm{MJ} / \mathrm{kgDM})$ was significantly higher than $D_{1}(5.30 \mathrm{MJ} / \mathrm{kgDM}), D_{2}(5.32$ $M J / k g D M)$ and $D_{3}(5.39 \mathrm{MJ} / \mathrm{kgDM})$. The OMD and SCFA followed the same trend.
\end{abstract}

Key words: Sweet orange peel meal, in vitro fermentation, in vitro gas production parameters, in vitro gas production characteristics,

\section{Introduction}

Increasing demand and consequently high cost of conventional animal feedstuffs in the tropics has created the need for sustained alternatives, particularly natural feed resources indigenous to the region. In Nigeria, ruminants slowly gain weight in the rainy season and rapidly loose it in the dry season, yet in the traditional animal husbandary, ruminants in the tropics especially in Nigeria, are mainly fed with grasses, so that improved livestock production is not likely attainable and sustainable by grasses forage alone (Babayemi and Bamikole, 2006). Babayemi et al., (2003) had earlier reported that the forages are unimproved and low in nutritive values during the wet season, while during the dry season proper, they are fibrous, lignified with low protein values and even in short supply. Recently, Lamidi et al., (2010) agreed to this by reporting that, the available forages for most part of the year are low in protein content which leads to marked decrease in voluntary intake and digestibility, and subsequently leads to substantial weight loss of the animals during this period. The success of the livestock industry anywhere in the world depends greatly on feed quantity and quality. Ruminants do better when energy and protein rich diets are strategically combined for feeding (Adegbola and Asaola, 1986). However, the expensive nature of conventional feed as a result of competition between man and livestock (Ogunbosoye and Babayemi, 2010), makes this combination difficult. Thus, there is the need to source for locally available feedstuffs which are less expensive and viable. In Nigeria, sweet orange (Citrus sinensis) peels is one such agricultural by-product. In vitro gas production technique is a quick, cheap and accurate method of assessing nutritive values of feedstuff (Menke et al., 1979). It involves volumetric measurement of gas production in phosphate and bicarbonate buffered in vitro incubation in syringes. Although, gas produced during rumen fermentation are waste products and of no nutritive value to the ruminants, gas production tests are used routinely in feed research as gas volumes are related to both the extent and rate of substrate degradation (Blummel et al., 1997). This study was therefore designed to assess the chemical composition, in vitro gas production parameters and in vitro gas production characteristics of diets containing varying levels of sweet orange (Citrus sinensis) peel meal

\section{Material and Method}

Sweet orange peels were collected from sweet orange retailers who peel and sell oranges for direct consumption. They were sun-dried on concrete floor for $48 \mathrm{hrs}$ and when dried, it was packed and crushed using a mortar and pestle and packed into synthetic bags. Four diets were compounded to contain $0 \%, 12.5 \%, 25 \%$ and 50\% SOPM designated as treatment 1,2,3 and 4 respectively. Sample from each treatment was ground in a hammer mill to pass through a $1 \mathrm{~mm}$ sieve. Each sample was analysed for crude protein, crude fibre, ether extract and ash according to the method of AOAC (1995). The in vitro gas production volume was determined 
according to Menke and Steingass (1988). Rumen liquor was obtained from four male West African dwarf goats in the morning before feeding. $200 \mathrm{mg}$ of each sample was placed in a $120 \mathrm{ml}$ calibrated syringe in triplicates and $30 \mathrm{ml}$ innoculum containing cheese strained rumen liquor and buffer solution in a ratio of 1:4 was added to the $200 \mathrm{mg}$ of feed in the plastic syringes. Metabolizable energy (ME/MJ/kgDM) and organic matter digestibility (OMD\%) were estimated as established by Menke and Steingass (1988), while short chain fatty acids (SCFA) were calculated as described by Getachew et al. (1998). Gas production characteristics were estimated using the equation $\mathrm{Y}=\mathrm{a}+\mathrm{b}\left(1-\mathrm{e}^{-\mathrm{ct}}\right)$ (Orskov and MacDonald, 1979), where $\mathrm{Y}=$ volume of gas produced in time $\mathrm{t}, \mathrm{a}=$ gas produced from the soluble fraction, $\mathrm{b}=$ gas produced from the insoluble but fermentable fraction, $\mathrm{c}=$ gas production rate constant for the insoluble but fermentable fraction ' $\mathrm{b}$ ' while $\mathrm{t}=$ incubation time. Metabolizable energy (ME, $\mathrm{MJ} / \mathrm{kgDM})$ and organic matter digestibility (OMD, \%) were estimated as established by Menke and Steingass, 1988) and short chain fatty acids (SCFA) were computed as reported by Getachew et al. (1998). $\mathrm{ME}=2.20+0.136 \mathrm{GV}+0.057 \mathrm{CP}+0.002 \mathrm{CF}, \mathrm{OMD}=14.89+0.889 \mathrm{GV}+0.45 \mathrm{CP}+0.651 \mathrm{XA}$

$\mathrm{SCFA}=0.0239 \mathrm{GV}-0.0601$, Where $\mathrm{GV}, \mathrm{CP}, \mathrm{CF}$ and $\mathrm{XA}=$ gas production volume $(\mathrm{ml} / 200 \mathrm{mgDM})$, crude protein (\%), crude fibre (\%) and ash (\%) of the incubated sample.

Data collected were subjected to analysis of variance (ANOVA) using the Minitab (1991) software in completely randomized design. Significant differences were separated using the least square difference (LSD) as outlined by Akindele (1996).

\section{Results and discussion}

Table 1 presents the gross and chemical composition of the four diets. Crude protein values were between $14.72-16.41 \%, \mathrm{D}_{1}(16.41 \%), \mathrm{D}_{2}(16.00 \%)$ and $\mathrm{D}_{3}(16.23 \%)$ had similar values while $\mathrm{D}_{4}(14.72 \%)$ was lower. This was probably so because of the higher percentage of SOPM in $\mathrm{D}_{4}$ and also that SOPM is lower in CP than maize offal. Observed values were comparable to $16.97-17.48 \%$ reported by Arigbede et al. (2010) for diets containing graded levels of cocoa yam. Crude fibre values ranged between 11.05-14.22\%, while the NFE was $40.61-45.84 \%$. The NFE values indicated that there was sufficient fermentable carbohydrates in the diets for energy production. Nitrogen free extract values were highest in $\mathrm{D}_{4}(54.93)$ this may be as a result of the higher level of SOPM in $\mathrm{D}_{4}$. Observed NFE values were comparable with $42.87-43.77 \%$ reported by Ukanwoko et al. (2009) for WAD goats fed cassava peel-cassava leaf meal, but it was higher than 28.04-32.97\% reported by Maigandi and Abubakar (2004) for diets containing Faidherbia albida pods. Ash values which were between 9.01-9.82\% indicated that, there was appreciable amount of minerals in the diets. Table 2 presents the in vitro gas production volumes, metabolisable energy, organic matter digestibility and short chain fatty acid of the diets containing varrying levels of sweet orange peel meal. Values of IVGP for $\mathrm{D}_{4}(24.67 \mathrm{ml} / 200 \mathrm{mgDM})$ was significantly higher $(p<0.05)$ than those of $\mathrm{D}_{1}(15.33 \mathrm{ml} / 200 \mathrm{mgDM}) \quad \mathrm{D}_{2}(17.33 \mathrm{ml} / 200 \mathrm{mgDM})$ and $\mathrm{D}_{3}(20.33 \mathrm{ml} / 200 \mathrm{mgDM})$. This means that more carbohydrate fermentation took place in $\mathrm{D}_{4}(50 \% \mathrm{SOPM})$ and also that $\mathrm{D}_{4}$ had higher nutritive potentials than the other diets. The ME values were 5.30-6.50 MJ $/ \mathrm{kgDM}$, OMD was $40.57-49.18 \%$ and SCFA was $0.30-0.53 \mathrm{mmol} / 200 \mathrm{mgDM}$. Diet 4 was significantly higher $(\mathrm{p}<0.05)$ in ME, OMD and SCFA, implying that $\mathrm{D}_{4}$ had higher energy potentials than the other diets because high ME and SCFA implies energy availability. This agrees with the report of Sallam et al. (2007) that, high SCFA is an indicator of energy availability. Observed ME, OMD and SCFA values were comparable with the report of Abegunde et al. (2010) who reported 4.45-5.99 MJ/kgDM, 38.32-50.33\% and 0.25-0.51 mmol $/ 200 \mathrm{mgDm}$ for ME, OMD and SCFA respectively for Ficus exasperata diets. Table 3 shows the in vitro gas production characteristics of the experimental diets. The gas production characteristics of the diets did not show any significant difference $(p>0.05)$ among the treatments. The soluble fraction ' $a$ ' $(6.08-8.25 \mathrm{ml} / 200 \mathrm{mgDM})$ and the potential gas production ' $b$ ' $(16.23-30.88 \mathrm{ml} / 200 \mathrm{mg})$ were all similar. This indicates that there was no difference in nutritive value among dietary treatments in the soluble carbohydrates and the insoluble but fermentable carbohydrates. The ' $b$ ' values were comparable with 19.00-26.00ml/200mgDM reported by Binuomote et al. (2010) for ensiled cassava tops and guinea grass mixture. The rate constant of fermentation ' $c$ ' for $\mathrm{D}_{1}-\mathrm{D}_{4}$ which ranged between $0.03-0.07 \mathrm{ml} / \mathrm{hr}$ was comparable with $0.04-0.06 \mathrm{ml} / \mathrm{hr}$ reported by Binuomote et al. (2010) for ensiled cassava tops and guinea grass mixture.

\section{Conclusion}

In vitro gas production parameters improved with increasing levels of SOPM in the diets, while there was no treatment effect on the gas production characteristics. The study showed that treatment with the highest percentage of SOPM had the highest energy potential, and increasing the levels of the test ingredient in the diets did not exert harmful effect on the activities of the rumen micro-organisms so as to cause retardation. 
Table 1: Gross and chemical composition of experimental diets fed to West African Dwarf goats

(DM basis)

\begin{tabular}{|c|c|c|c|c|}
\hline \multirow[t]{2}{*}{ Feed Ingredients } & \multicolumn{4}{|c|}{ Experimental Diets } \\
\hline & $\mathrm{D}_{1}$ & $\mathrm{D}_{2}$ & $\mathrm{D}_{3}$ & $\mathrm{D}_{4}$ \\
\hline Rice offal & 20.00 & 20.00 & 20.00 & 20.00 \\
\hline Maize offal & 48.81 & 42.71 & 36.61 & 24.41 \\
\hline Sweet orange peel meal & 0 & 6.10 & 12.20 & 24.40 \\
\hline Full fat Soyabean meal & 28.19 & 28.19 & 28.19 & 28.19 \\
\hline Bone ash & 2.00 & 2.00 & 2.00 & 2.00 \\
\hline Common salt & 1.00 & 1.00 & 1.00 & 1.00 \\
\hline Total & 100.00 & 100.00 & 100.00 & 100.00 \\
\hline \multicolumn{5}{|l|}{ Determined } \\
\hline Crude prorein & 16.41 & 16.00 & 16.23 & 14.72 \\
\hline Crude fibre & 14.22 & 13.16 & 11.05 & 12.27 \\
\hline Ether extract & 9.55 & 7.58 & 8.67 & 6.02 \\
\hline Nitrogen free extract & 50.81 & 53.84 & 54.93 & 57.93 \\
\hline Ash & 9.01 & 9.42 & 9.12 & 9.82 \\
\hline
\end{tabular}

$\mathrm{DM}=$ Dry matter, $\mathrm{T} 1=0 \% \mathrm{SOPM}, \mathrm{T} 2=12.5 \% \mathrm{SOPM}$

$\mathrm{T} 3=25 \% \mathrm{SOPM}, \mathrm{T} 4=50 \% \mathrm{SOPM}$

Table 2: In vitro gas production, metabolisable energy, organic matter digestibility and short chain fatty acid of diets containing graded levels of sweet orange peel meal

\begin{tabular}{|c|c|c|c|c|}
\hline \multirow[b]{2}{*}{ Diets } & \multicolumn{3}{|c|}{ In vitro parameters } & \multirow[b]{2}{*}{$\mathrm{SCFA}(\mu \mathrm{mol} / 200 \mathrm{mgDM})$} \\
\hline & IVGP & $\mathrm{ME}(\mathrm{MJ} / \mathrm{kgDM})$ & OMD (\%) & \\
\hline $\mathrm{D}_{1}(0 \%$ SOPM $)$ & $15.33^{b}$ & $5.30^{\mathrm{c}}$ & $40.57^{\mathrm{c}}$ & $0.30^{\mathrm{d}}$ \\
\hline $\mathrm{D}_{2}(12.5 \% \mathrm{SOPM})$ & $17.33^{\mathrm{b}}$ & $5.52^{\mathrm{bc}}$ & $42.42^{\mathrm{bc}}$ & $0.35^{\mathrm{b}}$ \\
\hline $\mathrm{D}_{3}(25 \% \mathrm{SOPM})$ & $20.33^{b}$ & $5.39^{\mathrm{b}}$ & $41.41^{\mathrm{b}}$ & $0.32^{\mathrm{c}}$ \\
\hline $\mathrm{D}_{4}(50 \% \mathrm{SOPM})$ & $24.67^{\mathrm{a}}$ & $6.56^{\mathrm{a}}$ & $49.18^{\mathrm{a}}$ & $0.53^{\mathrm{a}}$ \\
\hline SEM & $2.08^{*}$ & $0.08 *$ & $0.51 *$ & $0.01 *$ \\
\hline
\end{tabular}

$\mathrm{a}, \mathrm{b}, \mathrm{c}=$ Means on the same column with different superscripts are significantly different $(\mathrm{p}<0.05)$

$*=$ significant $(\mathrm{p}<0.05), \mathrm{SEM}=$ Standard error of the mean, IVGP $=$ In vitro gas production

$\mathrm{ME}=$ Metabolisable energy, $\mathrm{OMD}=$ Organic matter digestibility, $\mathrm{SCFA}=$ Short chain fatty acid, and SOPM $=$ Sweet orange peel meal.

Table 3: In vitro gas production characteristics of the experimental diets ( $\mathrm{ml} / 200 \mathrm{mgDM})$

\begin{tabular}{|c|c|c|c|c|c|}
\hline \multirow{2}{*}{$\begin{array}{l}\text { Fermentation } \\
\text { Characteristics }\end{array}$} & \multicolumn{4}{|c|}{ Treatment diets } & \multirow[b]{2}{*}{ SEM } \\
\hline & $\mathrm{D}_{1}$ & $\mathrm{D}_{2}$ & $\mathrm{D}_{3}$ & $\mathrm{D}_{4}$ & \\
\hline 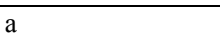 & 7.81 & 8.25 & 6.08 & 7.70 & $1.37^{\mathrm{ns}}$ \\
\hline$a+b$ & 24.04 & 27.49 & 23.79 & 38.59 & $10.17^{\mathrm{ns}}$ \\
\hline B & 16.23 & 19.20 & 17.70 & 30.88 & $9.15^{\mathrm{ns}}$ \\
\hline $\mathrm{C}$ & 0.05 & 0.03 & 0.07 & 0.05 & $0.01^{\mathrm{ns}}$ \\
\hline Lag & 8.58 & 8.30 & 5.30 & 5.40 & $2.02^{\mathrm{ns}}$ \\
\hline
\end{tabular}

$\mathrm{ns}=$ Not significant, SEM $=$ Standard error of the mean

$a=$ Soluble fraction

$a+b=$ Potentially degradable fraction

$\mathrm{b}=$ Potential gas production

$\mathrm{c}=$ Rate of fermentation constant

\section{References}

[1]. Abegunde, T.O., Mako, A.A., Adene, I.C., Akinsoyinu, A.O and Babayemi, O.J. (2010)

[2]. Chemical compostion and in vitro gas production parameters of Ficus exasperate diets in the dry and wet season of Nigeria. Proc. $35^{\text {th }}$ Conf., Nig. Soc. for Anim. Prod. held on the $14^{\text {th }}-17^{\text {th }}$ March, 2010, Univ. of Ibadan. Nig. Pp. $580-583$.

[3]. Adegbola, A. A. and Asaola, V. O. (1986). Preparation of cassava peels used in small ruminant production in Western Nigeria. Proc. of workshop held at the University of Alexandria. Egypt. Oct. 1985. ILCA. Addis Ababa. Ethiopia. Pp. 109 - 115.

[4]. Aganga, A. A., Umunna, N. N., Okoh, P. N. and Oyedipe, E. O. (1986). Water metabolism of ruminants. J.Anim. Prod. Res. 6 (2): $171-187$.

[5]. Akindele, S. O. (1996). Basic Experimental Designs in Agricultural Research. Montem paperbacks ,akure Nigeria. Pp. 25 - 34.

[6]. AOAC (1995). Official method of Analysis (16 ${ }^{\text {th }}$ edition) Association of official Analytical Chemists, Washington DC.

[7]. Babayemi, O.J., Bamikole, M.A and Odunguwa B.O. (2003). Haematological and biochemical components of West African dwarf goats fed Tephrosia bracteolata - based forage. Trop. Anim. Prod. Invest. 6:31-38.

[8]. Babayemi, O. J. and Bamikole, M. A. (2006). Nutritive value of Tephosia candida seed in West African Dwarf goats. J. Cent. Eur. Agric. 7:4, $731-738$.

[9]. Binuomote, R. T. and Babayemi, O. J. (2010). Nutritive evaluation of ensile cassava (Manihot esculentus, crants) tops and guinea grass mixtures. Proc. $35^{\text {th }}$ Conf., Nig. Soc. for Anim. Prod. $14^{\text {th }}-17^{\text {th }}$ March, 2011, Univ. of Ibadan, Nigeria. Pp. $601-603$.

[10]. Blummel, M., Makkar, H.P.S., Chisanga, G., Mtimuni and Becker, K. (1997). The prediction of dry matter intake and in vitro digestibility of African roughages in relation to ruminant live weight gain. Anim. Feed Sci. and Tech. 69:131 - 141. 
[11]. Getachew, G., Blummel, M., Makkar, H. P and Becker, K. (1998). In vitro gas measuring techniques for assessment of nutritional quality of feeds. A review. Anim. feed. Sci. Technolo. 72: $261-281$.

[12]. Lamidi, A.A., Aina, A.B.J and Sowande, S.O. (2010). Nutrient digestibility and nitrogen balance in West African dwarf goats fed blended diets for dry season. Proc. $35^{\text {th }}$ Conf. Nig. Soc. Anim. Prod. held $14^{\text {th }}-17^{\text {th }}$ March, 2010 at the Univ. of Ibadan, Nigeria. Pp. $499-501$.

[13]. Maigandi, S.A and Abubakar, S. (2004). Nutrient intake and digestibility by red Sokoto goats fed varying levels of Faigherbial albida pods. Proc. $29^{\text {th }}$ Ann. Conf., Nig Soc. Anim. Prod. Vol. 29:325 - 328.

[14]. Menke, K. H and Steinguss, H. (1988). Estimation of the energetic feed value from chemical analysis and in vitro gas production using rumen fluid. Anim. Res. Develop. 28: 7 - 55

[15]. Menke, K. H and Steinguss, H. (1988). Estimation of the energetic feed value from chemical analysis and in vitro gas production using rumen fluid. Anim. Res. Develop. 28: 7 - 55

[16]. MINITAB (1991). Statistical Software. Vol.10. 2 MINITAB Inc. P.A., USA

[17]. Ogunbosoye, D. O. and Babayemi, O. J. (2010). Voluntary intake of Non-legume fodders offered simultaneously to West African Dwarf goats for a period of six hours. Proc. $35^{\text {th }}$ Conf. Nig. Soc. for Anim. Prod. $14-17^{\text {th }}$ March, 2010, Univ. of Ibadan, Nigeria. Pp. $518-520$.

[18]. Sallam, S.M.A., Nasser, M.E.A., El-Waziri, A.M., Bueno, I.C.S and Abdalla, A.L. (2007). Use of in vitro rumen gas production technique to evaluate feedstuffs. J. Appl. Sci. and Res. $3 \quad$ (1): $34-41$.

[19]. Ukanwoko, A. I., Ibeawuchi, J. A. and Ukachukwu, N. N. (2009). Growth Performance and carcass characteristics of West African dwarf goats fed cassava peel-cassava leaf meal based diet. Proc. $34^{\text {th }}$ Ann. Conf., Nig. Soc. for Anim. Prod. 15-18 ${ }^{\text {th }}$ March, 2009. Univ. of Uyo, Uyo. Pp. $476-479$.

[20]. Menke, K.H., Ranb, L., Salewski, A., Steingass., Fritz, D. and Schneider, W. (1979). The estimation of the digestibility and Metabolizable energy content of ruminant feedstuffs from gas Production when they are incubated with human liquors nitrogen. $J$. Agric. Sc. 93: $217-222$. 